\title{
Effect of novel natural feed additive containing Averrhoa bilimbi L. fruit filtrate, wheat bran, and Saccharomyces cerevisiae on growth performance and meat characteristics of broilers
}

\author{
Sugiharto Sugiharto ${ }^{1}$, Anugrah R. Pratama ${ }^{1}$, Turrini Yudiarti ${ }^{1}$ (D) and Tugay Ayaşan² ${ }^{2}$
}

1. Department of Animal Science, Faculty of Animal and Agricultural Sciences, Universitas Diponegoro, Semarang, Central Java, Indonesia; 2. Department of Organic Farming Business Management, Kadirli Faculty of Applied Sciences, University of Korkut Ata, Osmaniye, Turkey.

Corresponding author: Sugiharto Sugiharto, e-mail: sgh_undip@yahoo.co.id

Co-authors: ARP: anugrahrobby18@gmail.com, TY: tyudiarti@yahoo.co.id, TA: tayasan@gmail.com

Received: 28-07-2021, Accepted: 27-10-2021, Published online: 27-11-2021

doi: www.doi.org/10.14202/vetworld.2021.3007-3014 How to cite this article: Sugiharto S, Pratama AR, Yudiarti T, Ayaşan T (2021) Effect of novel natural feed additive containing Averrhoa bilimbi L. fruit filtrate, wheat bran, and Saccharomyces cerevisiae on growth performance and meat characteristics of broilers, Veterinary World, 14(11): 3007-3014.

\begin{abstract}
Background and Aim: In the post-antibiotic era, consumer demand for healthy and safe meats has prompted poultry producers to seek alternative effective feed additives. This study aimed to investigate the effects of a novel natural feed additive based on a mixture of Averrhoa bilimbi L. fruit filtrate, wheat bran, and Saccharomyces cerevisiae on the growth rate, internal organ weight, and breast meat characteristics of broilers.

Materials and Methods: A total of 280 1-day-old chicks were divided into one control (CNTRL; feed without additives) and three treatment groups: NOV25, feed with $2.5 \mathrm{~g} / \mathrm{kg}$ novel additive; NOV50, feed with $5.0 \mathrm{~g} / \mathrm{kg}$ novel additive; and NOV100, feed with $10 \mathrm{~g} / \mathrm{kg}$ novel additive. The body weight (BW), feed intake (FI), and feed conversion ratio (FCR) were measured weekly. On day 35, the chickens from each group were slaughtered, and their internal organs and breast meat samples were collected.

Results: The BW of broilers in NOV100 was greater $(\mathrm{p}=0.016)$ than that in the other groups. The FCRs in the treatments groups were lower $(p<0.001)$ than that in the control group. Elevated levels of the novel additive increased $(p=0.051)$ the relative weight of the duodenum. The $\mathrm{pH}$ values in the breast meat of broilers receiving the novel additive were higher $(\mathrm{p}<0.001)$ than that in control. The C20:3n-6 of the NOV100 breast meat was lower $(\mathrm{p}=0.012)$ than that of NOV25 and NOV50, but it did not differ from that of the control. The unsaturated fatty acid-to-saturated fatty acid ratio in the breast meats of the treatments was higher $(\mathrm{p}=0.032)$ than that in control. The L-tyrosine content in NOV50 breast meat was higher $(\mathrm{p}=0.036)$ than that in CNTRL and NOV100 but did not differ from that in NOV25.
\end{abstract}

Conclusion: The proposed feed additive improved the live BW and FCR of broilers and the physical and nutritional qualities of broiler breast meat.

Keywords: Averrhoa bilimbi L. fruit filtrate, breast meat, broiler, natural feed additive, organic acid.

\section{Introduction}

The broiler industry has expanded steadily in Indonesia over the past 10 years, representing a substantial part of the national economy today [1]. To optimize broiler productivity and health in the post-antibiotic era, farmers commonly use feed additives. These additives include probiotics, prebiotics, synbiotics, organic acids, enzymes, fatty acids, and phytobiotics or plant-derived products [2]. Indonesia is known for its abundance of medicinal plants, which are used as additives and supplements for livestock in addition to being used for human medicine. Averrhoa bilimbi L. is one of several herbal plants with the potential to be used as an additive for broilers. The fruit filtrate of

Copyright: Sugiharto, et al. Open Access. This article is distributed under the terms of the Creative Commons Attribution 4.0 International License (http://creativecommons.org/licenses/ by/4.0/), which permits unrestricted use, distribution, and reproduction in any medium, provided you give appropriate credit to the original author(s) and the source, provide a link to the Creative Commons license, and indicate if changes were made. The Creative Commons Public Domain Dedication waiver (http:// creativecommons.org/publicdomain/zero/1.0/) applies to the data made available in this article, unless otherwise stated. this plant is naturally acidic (high in citric acid) and can be used as a natural acidifier to increase broiler growth and improve health $[3,4]$. It contains lactic acid bacteria (LAB) [3,5], which function as probiotics for broiler chickens [4]. A previous study reported that using acidifiers and probiotics in combination had a greater impact on broiler production and health than using an acidifier and probiotic separately [2]. In addition, several studies have reported that combining probiotics with prebiotics increased probiotic efficacy compared with using probiotics alone [6,7]. Wheat bran has been identified as a prebiotic-rich and affordable feed ingredient for broiler chickens [8]. This by-product of the wheat milling industry is rich in arabinoxylan oligosaccharides, which function as an energy source for bacteria [9].

Consumers are becoming increasingly aware of the quality and health impacts of the meat they consume. This has prompted broiler farmers to produce healthier meats. Dietary supplementation of organic acids reduces the contents of saturated fatty acids (SFAs) and increases the polyunsaturated fatty acids 
(PUFAs) of broiler meat [10]. In another study, feeding LAB-based probiotics and Saccharomyces cerevisiae to broilers improved fatty acid profiles of the meat [11]. Similarly, feeding prebiotics increased the proportions of PUFA and n-3 PUFA in broiler meats [12]. We, therefore, hypothesized that combining acidifiers, probiotics, and prebiotics in a feed additive would improve the productive performance and meat quality of broiler chickens through synergistic effects. For this study, the fruit filtrate of $A$. bilimbi $\mathrm{L}$. was used as an acidifier and source of probiotic LAB, and prebiotics were derived from wheat bran. To augment the probiotic effect, the yeast $S$. cerevisiae was added to the feed additive.

The aim of this study was to assess the effect of a novel natural feed additive based on a mixture of A. bilimbi L. fruit filtrate, wheat bran, and $S$. cerevisiae on growth rate, internal organ weight, and breast meat traits of broilers.

\section{Materials and Methods \\ Ethical approval}

The Committee of Animal Ethics of the Faculty of Animal and Agricultural Sciences, Universitas Diponegoro approved the in vivo experiment (No. 57-02/A3/KEP/FPP), which was carried out in conjunction with the standard animal husbandry and health guidelines outlined in Legislation of the Republic of Indonesia No. 18, 2009.

\section{Study period and location}

The study was conducted from January to March 2021 at the Broiler Experimental House of the Faculty of Animal and Agricultural Sciences, Universitas Diponegoro, Semarang, Central Java, Indonesia.

\section{Production of feed additive}

Ripe $A$. bilimbi L. fruits (identified by Department of Biology, the Faculty of Science and Mathematics, Universitas Diponegoro, Semarang) were gathered from the local campus gardens (Tembalang Campus, Semarang, Central Java, Indonesia), cleaned with water, and then crushed using a portable electric blender at medium speed. The fruit juice was filtered using a cheese cloth, and the obtained fruit filtrate ( $\mathrm{pH}$ 1.98) was used to ferment the wheat bran. Before fermentation, the wheat bran was prepared according to Utama et al. [13]. Bran was added to distilled water at a ratio of $3: 1(\mathrm{~g}: \mathrm{mL})$; the solution was thoroughly mixed, autoclaved (electric All-American ${ }^{\circledR}$ Sterilizer, Westbury, NY, USA) at $121^{\circ} \mathrm{C}$ for $15 \mathrm{~min}$, and then left to cool down to room temperature (around $25^{\circ} \mathrm{C}$ ). To produce the feed additive, the autoclaved wheat bran was mixed with the fruit filtrate at a ratio of 1:4 (g: $\mathrm{mL}$ ) and incubated anaerobically using an anaerobic jar (Oxoid, Thermo Fisher Scientific, Waltham, MA, USA) at $38^{\circ} \mathrm{C}$ for 2 days. The fermented product was subsequently sun-dried and milled using an electric grinder (Panasonic Grinder MXGX1462, PT. Panasonic Gobel Indonesia, Jakarta, Indonesia).
Finally, the fermented product was combined with commercial yeast $S$. cerevisiae at a ratio of $2: 1$ (g: g; Angel Yeast Co. Ltd., Hubei, China; contained $9.82 \times 10^{11}$ colony forming unit $[\mathrm{CFU}] / \mathrm{g}$ ). The natural feed additive contained LAB of $5.47 \times 10^{11} \mathrm{CFU} / \mathrm{g}$ (based on the total plate count method using de Man, Rogosa, and Sharpe agar, incubated at $38^{\circ} \mathrm{C}$ for $48 \mathrm{~h}$ [14]) with $\mathrm{pH} 4.65$. Based on a standard proximate analysis, the feed additive contained $9.85 \%$ moisture, $14.86 \%$ crude protein, $0.30 \%$ crude fat, $1.66 \%$ fiber, and $8.72 \%$ ash (on a dry matter basis).

\section{In vivo experiment}

For the experiment, 280 1-day-old chicks (unsexed Lohmann MB-202 broiler strain; average body weight $[\mathrm{BW}]$ of $48.2 \pm 0.26 \mathrm{~g}$ ) were divided into four treatment groups with seven replications (each containing 10 chicks). These treatment groups included the control (CNTRL; feed without the additive), NOV25 (feed with $2.5 \mathrm{~g} / \mathrm{kg}$ of the additive), NOV50 (feed with $5.0 \mathrm{~g} / \mathrm{kg}$ of the additive), and NOV100 (feed with $10 \mathrm{~g} / \mathrm{kg}$ of the additive). The birds were reared for 35 days in an opened broiler house in $1 \mathrm{~m}^{2}$ pens. The photoperiod was $24 \mathrm{~h}$ light. Plastic curtains and light bulbs were used to regulate the temperature and relative humidity in the broiler house. The temperature was $32^{\circ} \mathrm{C}$ for the first 4 days and $28-29^{\circ} \mathrm{C}$ for the remainder of the experiment. The relative humidity was maintained at approximately $80 \%$.

Feeds were prepared in mash form following the Indonesian National Standards for Broiler Feed [15] as starter (days 1-21) and finisher (days 22-35) diets (Table-1) [16]. During the mixing process, the additives were added proportionately to the main feed according to the ratio of the specific treatment group. No antibiotics or other additives such as enzymes, phytase, amylase, carbohydrases, or coccidiostats were added. Feed and water were provided ad libitum in each pen using a manual feeder/drinker. The birds were immunized with Newcastle disease vaccine through eye drops and drinking water on days 4 and 18 , respectively. On day 12 , they were given the Gumboro (infectious bursal disease) vaccine through their drinking water.

\section{Data collection and analysis}

The live BW, amount of feed intake, and feed conversion ratio (FCR) of chicks were determined weekly. On day 35, one chick from each pen (seven chicks per treatment group) was slaughtered, defeathered, and dissected. The internal organs of the birds were collected and weighed (empty condition) using an analytical balance (Henherr, ACS-718, China). The carcass and commercial cuts (breast, wings, thigh, drumstick, and back) were also inspected. Likewise, the meat samples were collected from the breast to determine physical properties such as water-holding capacity (WHC) and $\mathrm{pH}$, as well as fatty acid and amino acid profiles.

The WHC of breast meats was measured using the Grau-Hamm [17] method. The pH of the meat 
Table-1: Ingredients and nutritional compositions of feeds.

\begin{tabular}{lcc}
\hline $\begin{array}{l}\text { Item (\%, unless otherwise } \\
\text { noticed) }\end{array}$ & $\begin{array}{c}\text { Starter } \\
\text { (days } \\
\mathbf{1 - 2 1 )}\end{array}$ & $\begin{array}{c}\text { Finisher } \\
\text { (days }\end{array}$ \\
$\mathbf{2 2 - 3 5 )}$
\end{tabular}

${ }^{1}$ Provided per $\mathrm{kg}$ of feed: $1100 \mathrm{mg} \mathrm{Zn,} 1000 \mathrm{mg} \mathrm{Mn}$, $75 \mathrm{mg} \mathrm{Cu}, 850 \mathrm{mg} \mathrm{Fe}, 4 \mathrm{mg} \mathrm{Se}, 19 \mathrm{mg} \mathrm{I}, 6 \mathrm{mg} \mathrm{Co}$,

1225 mg K, 1225 mg Mg, 1,250,000 IU Vitamin A, 250,000 IU Vitamin $D_{3} 1350 \mathrm{~g}$ pantothenic acid, $1875 \mathrm{~g}$

Vitamin E, $250 \mathrm{~g}$ Vitamin $\mathrm{K}_{3}, 250 \mathrm{~g}$ Vitamin $\mathrm{B}_{1}, 750 \mathrm{~g}$ Vitamin $\mathrm{B}_{2}, 500 \mathrm{~g}$ Vitamin $\mathrm{B}_{6}, 2500 \mathrm{mg}$ Vitamin $\mathrm{B}_{12}, 5000 \mathrm{~g}$ niacin, $125 \mathrm{~g}$ folic acid, and $2500 \mathrm{mg}$ biotin. ${ }^{2}$ Metabolizable energy was predicted based on formula [16]: $40.81(0.87$ [crude protein +2.25 crude fat+nitrogen-free extract] +2.5 )

was measured using a portable $\mathrm{pH}$ meter (OHAUS ST300, Ohaus, Parsippany, NJ, USA). The concentrations of fatty acids in the breast meat samples were measured using a standard gas chromatography (Shimadzu Corporation, Kyoto, Japan) method. The presence of fatty acids was determined by comparing the retention times of each sample to the retention times of standard. Fatty acid quantification was performed by normalizing and converting the area percentage to $\mathrm{g} / 100 \mathrm{~g}$ of the edible section using a lipid conversion factor [18]. The amino acid content of the breast meat samples was determined using a typical ultra-performance liquid chromatography protocol (Waters, Massachusetts, USA) according to the Waters Acquity UPLC H-Class and H-Class Bio Amino Acid Analysis System Guide [19]. The process employed a $1.7 \mathrm{~m}(2.1 \times 100 \mathrm{~mm})$ AccQ.Tag Ultra C18 column with a column temperature of $49^{\circ} \mathrm{C}$, handheld phase flow speeds of $0.5 \mathrm{~mL} / \mathrm{min}, 1 \mu \mathrm{L}$ of injection capacity, and a photometric diode array (Waters) detector with the $260 \mathrm{~nm}$ wavelength. The mobile step composition schemes were as follows: Eluent A Amino Acid Analysis AccQ.Tag Ultra concentrate; Eluent B Amino Acid Analysis AccQ.Tag Ultra 10\% in water; C: Distilled water; and D: Eluent B Amino Acid Analysis AccQ.Tag Ultra.

\section{Statistical analyses}

Data were tested for normal distribution and homogeneity of variance and then analyzed using analysis of variance (ANOVA, Statistical Package for the Social Sciences 16.0 version, SPSS Inc., Chicago, IL, USA). For treatments with $\mathrm{p}<0.05$, a Duncan multirange test was performed. The influence of the different levels of additives in the treatments was assessed using linear regression. Pens/replicates were regarded as the experimental units. The normal distribution and homogeneity of variance were tested before ANOVA test. The tendency was considered when $p>0.050$ and $p<0.100$.

\section{Results}

\section{Broiler performance}

Data for BW, feed intake (FI), and FCR of the broilers are listed in Table-2. On days 21 and 35, the live BW of broilers in NOV100 was higher ( $\mathrm{p}=0.026$ and $\mathrm{p}=0.016$, respectively) than that of the other groups. The cumulative FI in NOV50 was lower $(p=0.038)$ than that in CTRL and NOV100, but it did not differ from that in NOV25 on day 35 . The FCR in NOV100 was lower $(\mathrm{p}<0.001)$ than that in CNTRL and NOV25, but it did not differ from that in NOV50.

\section{Internal organ weight and carcass yield of broilers}

Table-3 depicts internal organ weight (relative to the live BW). ANOVA indicated no influence $(p>0.050)$ of the dietary additive on the measured internal organ weight of broilers. However, the additive seemed to increase the weight of the duodenum.

Carcass weights and commercial proportions (Table-4) of chickens were not significantly affected by the treatments $(\mathrm{p}>0.050)$.

\section{Physical and chemical characteristics of the meat samples}

The breast meat $\mathrm{pH}$ values of the treatment groups were higher than that of the control, with NOV100 exhibiting the highest value. The WHC of the breast meat did not differ among all groups (Table-5).

Table- 6 presents the fatty acid compositions of broiler breast meat samples. NOV100 chicks had a lower ( $p=0.012)$ proportion of dihomo-gamma-linolenic acid $(\mathrm{C} 20: 3 \mathrm{n}-6)$ than chicks from NOV25 and NOV50. However, the proportion did not differ significantly from that of the CNTRL birds. The unsaturated fatty acid (UFA)-to-SFA ratio in the breast meat samples of NOV25, NOV50, and NOV100 was higher $(p=0.032)$ than that in CNTRL. Other fatty acids compositions did not vary significantly $(\mathrm{p}>0.050)$ among the groups.

Data on the amino acid profile of broiler meats are presented in Table-7. The NOV50 meats contained higher amino acid L-tyrosine than those of CNTRL and NOV100 $(p=0.036)$, but they did not differ significantly from that of NOV25 meat. There was no variation ( $p>0.050)$ in amino acid contents of broiler meats among the treatment groups. 
Table-2: Performances of broilers.

\begin{tabular}{|c|c|c|c|c|c|c|c|}
\hline \multirow[t]{2}{*}{ Item } & \multicolumn{4}{|c|}{ Treatment } & \multirow[t]{2}{*}{ SEM } & \multicolumn{2}{|c|}{ p-value } \\
\hline & CNTRL & NoV25 & NoV50 & NOV100 & & $\mathbf{A}$ & $\mathbf{L}$ \\
\hline \multicolumn{8}{|l|}{ Day 21} \\
\hline BW (g) & $618.8^{b}$ & $638.6^{b}$ & $637.2^{\mathrm{b}}$ & $688.1^{a}$ & 8.804 & 0.026 & 0.006 \\
\hline Accumulative FI (g) & 816.6 & 841.2 & 824.4 & 847.9 & 7.399 & 0.430 & 0.252 \\
\hline FCR & 1.431 & 1.432 & 1.403 & 1.328 & 0.016 & 0.068 & 0.017 \\
\hline \multicolumn{8}{|l|}{ Day 35} \\
\hline BW (g) & $1689^{\mathrm{b}}$ & $1710^{\mathrm{b}}$ & $1673^{b}$ & $1826^{a}$ & 19.62 & 0.016 & 0.031 \\
\hline Accumulative FI (g) & $2534^{a}$ & $2465^{\mathrm{ab}}$ & $2361^{b}$ & $2550^{a}$ & 26.56 & 0.038 & 0.818 \\
\hline FCR & $1.543^{\mathrm{a}}$ & $1.486^{\mathrm{b}}$ & $1.453^{b c}$ & $1.436^{c}$ & 0.011 & $<0.001$ & $<0.001$ \\
\hline
\end{tabular}

$a, b, c$ Means with various letters within the same row are substantially different $(p<0.05)$. CNTRL=Chicks given feed without additives, NOV25=Chicks given feed administrated with $0.25 \%$ novel additive, NOV50=Chicks given feed administrated with $0.50 \%$ novel additive, NOV100=Chicks given feed supplemented with $1.00 \%$ novel additive, BW=Body weight, $\mathrm{FI}=$ Feed intake, $\mathrm{FCR}=$ Feed conversion ratio, $\mathrm{A}=$ Analysis of variance (ANOVA), $\mathrm{L}=$ Linear regression, $\mathrm{SEM}=\mathrm{Standard}$ error of the means

Table-3: Relative weight of internal organ of broilers.

\begin{tabular}{|c|c|c|c|c|c|c|c|}
\hline \multirow[t]{2}{*}{ Item (\% live BW) } & \multicolumn{4}{|c|}{ Treatment } & \multirow[t]{2}{*}{ SEM } & \multicolumn{2}{|c|}{ p-value } \\
\hline & CNTRL & NoV25 & NoV50 & NOV100 & & A & $\mathbf{L}$ \\
\hline Heart & 0.501 & 0.526 & 0.503 & 0.491 & 0.011 & 0.722 & 0.584 \\
\hline Liver & 2.103 & 2.071 & 2.286 & 2.157 & 0.048 & 0.422 & 0.388 \\
\hline Proventriculus & 0.539 & 0.507 & 0.510 & 0.469 & 0.018 & 0.619 & 0.206 \\
\hline Gizzard & 1.404 & 1.393 & 1.480 & 1.407 & 0.031 & 0.759 & 0.734 \\
\hline Pancreas & 0.266 & 0.287 & 0.320 & 0.313 & 0.015 & 0.570 & 0.192 \\
\hline Duodenum & 0.378 & 0.459 & 0.476 & 0.476 & 0.018 & 0.163 & 0.051 \\
\hline Jejunum & 0.954 & 1.050 & 1.129 & 1.073 & 0.029 & 0.190 & 0.092 \\
\hline Ileum & 0.714 & 0.843 & 0.910 & 0.761 & 0.033 & 0.167 & 0.496 \\
\hline Caeca & 0.641 & 0.673 & 0.501 & 0.700 & 0.034 & 0.169 & 0.989 \\
\hline Abdominal fat & 0.751 & 1.093 & 0.946 & 1.007 & 0.064 & 0.294 & 0.299 \\
\hline Spleen & 0.103 & 0.127 & 0.114 & 0.127 & 0.001 & 0.853 & 0.728 \\
\hline Thymus & 0.269 & 0.267 & 0.247 & 0.266 & 0.015 & 0.961 & 0.839 \\
\hline Bursa of Fabricius & 0.160 & 0.183 & 0.173 & 0.160 & 0.011 & 0.880 & 0.988 \\
\hline
\end{tabular}

CNTRL=Chicks given feed without additives, NOV25=Chicks given feed administrated with $0.25 \%$ novel additive, NOV $50=$ Chicks given feed administrated with $0.50 \%$ novel additive, NOV100=Chicks given feed supplemented with

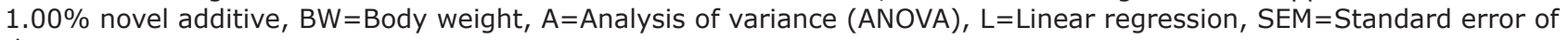
the means

Table-4: Carcass and commercial proportions of broilers.

\begin{tabular}{|c|c|c|c|c|c|c|c|}
\hline \multirow[t]{2}{*}{ Item } & \multicolumn{4}{|c|}{ Treatment } & \multirow[t]{2}{*}{ SEM } & \multicolumn{2}{|c|}{ p-value } \\
\hline & CNTRL & Nov25 & NoV50 & NOV100 & & $\mathbf{A}$ & $\mathbf{L}$ \\
\hline Eviscerated carcass ( $\%$ live BW) & 70.17 & $\begin{array}{l}69.06 \\
\% \text { evisc }\end{array}$ & $\begin{array}{c}65.69 \\
\text { ed carcass }\end{array}$ & 60.00 & 2.530 & 0.470 & 0.120 \\
\hline Breast & 37.17 & 38.01 & 36.35 & 33.37 & 1.457 & 0.689 & 0.301 \\
\hline Wings & 10.66 & 10.46 & 10.23 & 9.048 & 0.453 & 0.578 & 0.191 \\
\hline Thigh & 16.80 & 16.30 & 16.28 & 14.06 & 0.620 & 0.380 & 0.114 \\
\hline Drumstick & 14.47 & 13.77 & 14.98 & 12.36 & 0.550 & 0.358 & 0.249 \\
\hline Back & 20.89 & 21.46 & 22.16 & 18.76 & 0.822 & 0.501 & 0.383 \\
\hline
\end{tabular}

$\mathrm{CNTRL}=$ Chicks given feed without additives, NOV25=Chicks given feed administrated with $0.25 \%$ novel additive, NOV $50=$ Chicks given feed administrated with $0.50 \%$ novel additive, NOV100=Chicks given feed supplemented with $1.00 \%$ novel additive, $B W=$ Body weight, $A=$ Analysis of variance $(A N O V A), L=$ Linear regression, $S E M=S t a n d a r d$ error of the means

\section{Discussion}

Our results reveal that on days 21 and 35, dietary supplementation with the mixture of $A$. bilimbi L. fruit filtrate, wheat bran, and $S$. cerevisiae linearly increased the live BW and decreased the FCR of broilers with increasing levels of the additive. The most prominent effect was observed at a concentration of $10 \mathrm{~g} / \mathrm{kg}$ of feed. This treatment (containing crude protein of $14.86 \%$ ) increased the protein levels of the diet and consequently increased the broilers' growth rate. In this study, additive supplementation increased the relative weight of the duodenum, which seemed to be associated with an improved intestinal morphology [20], and it, hence, improved the intestinal functions of broilers in digesting and absorbing the nutrients. This is suggested by the improved FCRs in 
Table-5: Water-holding capacity and $\mathrm{pH}$ values of broiler meats.

\begin{tabular}{lccccccc}
\hline Item & \multicolumn{4}{c}{ Treatment } & & SEM & \multicolumn{2}{c}{ p-value } \\
\cline { 2 - 4 } & CNTRL & NOV25 & NOV50 & NOV100 & & A & L \\
\hline WHC (\%) & 35.89 & 36.98 & 36.55 & 36.93 & 0.170 & 0.081 & 0.084 \\
pH & $6.817^{\mathrm{c}}$ & $6.871^{\mathrm{b}}$ & $6.877^{\mathrm{b}}$ & $6.932^{\mathrm{a}}$ & 0.009 & $<0.001$ & $<0.001$ \\
\hline
\end{tabular}

a,bMeans with various letters within the same row are substantially different $(p<0.05)$. CNTRL=Chicks given feed without additives, NOV25=Chicks given feed administrated with $0.25 \%$ novel additive, NOV50=Chicks given feed administrated with $0.50 \%$ novel additive, NOV100=Chicks given feed supplemented with $1.00 \%$ novel additive, BW=Body weight, WHC =Water-holding capacity, $A=$ Analysis of variance (ANOVA), $L=$ Linear regression, SEM=Standard error of the means

Table-6: Fatty acid profiles of broiler meats.

\begin{tabular}{|c|c|c|c|c|c|c|c|}
\hline \multirow[t]{2}{*}{ Item $(\mathrm{g} / 100 \mathrm{~g})$} & \multicolumn{4}{|c|}{ Treatment } & \multirow[t]{2}{*}{ SEM } & \multicolumn{2}{|c|}{ p-value } \\
\hline & CNTRL & NOV25 & NoV50 & NOV100 & & A & $\mathbf{L}$ \\
\hline Myristic acid (C14:0) & 0.004 & 0.003 & 0.008 & 0.003 & $<0.001$ & 0.155 & 0.921 \\
\hline Pentadecylic acid (C15:0) & ND & ND & ND & ND & NA & NA & NA \\
\hline Palmitic acid (C16:0) & 0.222 & 0.216 & 0.358 & 0.149 & 0.031 & 0.094 & 0.784 \\
\hline Stearic acid (C18:0) & 0.084 & 0.082 & 0.117 & 0.053 & 0.009 & 0.072 & 0.481 \\
\hline Arachidic acid (C20:0) & ND & ND & ND & ND & NA & NA & NA \\
\hline Heneicosanoic acid (C21:0) & ND & ND & ND & ND & NA & NA & NA \\
\hline Behenic acid (C22:0) & ND & ND & ND & ND & NA & NA & NA \\
\hline Tricosylic acid (C23:0) & ND & ND & ND & ND & NA & NA & NA \\
\hline Lignoceric acid (C24:0) & ND & ND & ND & ND & NA & NA & NA \\
\hline Myristoleic acid (C14:1n9c) & ND & ND & ND & ND & NA & NA & NA \\
\hline Pentadecanoic acid (C15:1n9t) & ND & ND & ND & ND & NA & NA & NA \\
\hline Palmitoleic acid (C16:1n7) & 0.028 & 0.032 & 0.059 & 0.021 & 0.005 & 0.060 & 0.904 \\
\hline Oleic acid (C18:1n9c) & 0.333 & 0.336 & 0.561 & 0.242 & 0.049 & 0.129 & 0.918 \\
\hline Elaidic acid (C18:1n9t) & ND & ND & ND & ND & NA & NA & NA \\
\hline Eicosenoic acid (C20:1) & 0.003 & 0.003 & 0.004 & 0.003 & 0.001 & 0.948 & 0.834 \\
\hline Gondoic acid (C20:1n9) & ND & ND & ND & ND & NA & NA & NA \\
\hline Erucic acid (C22:1n9) & ND & ND & ND & ND & NA & NA & NA \\
\hline Nervonic acid (C24:1n9) & ND & ND & ND & ND & NA & NA & NA \\
\hline Linoleic acid (C18:2n-6c) & 0.153 & 0.154 & 0.248 & 0.105 & 0.021 & 0.095 & 0.788 \\
\hline Linolelaidic acid (C18:2n-6t) & ND & ND & ND & ND & NA & NA & NA \\
\hline Gamma-linolenic acid (C18:3n-6) & ND & ND & ND & ND & NA & NA & NA \\
\hline Alpha-linolenic acid (C18:3n-3) & 0.004 & 0.003 & 0.008 & 0.003 & 0.002 & 0.151 & 0.804 \\
\hline Eicosadienoic acid (C20:2n-6) & ND & ND & ND & ND & NA & NA & NA \\
\hline Dihomo-gamma-linolenic acid (C20:3n-6) & $0.008^{\mathrm{ab}}$ & $0.009^{a}$ & $0.011^{\mathrm{a}}$ & $0.004^{b}$ & 0.001 & 0.012 & 0.206 \\
\hline Eicosatrienoic acid (C20:3n-3) & ND & ND & ND & ND & NA & NA & NA \\
\hline Arachidic acid (C20:4n-6) & 0.028 & 0.034 & 0.036 & 0.018 & 0.003 & 0.110 & 0.255 \\
\hline Eicosapentaenoic acid, EPA (C20:5n-3) & ND & ND & ND & ND & NA & NA & NA \\
\hline Docosadienoic acid (C22:2n-6) & ND & ND & ND & ND & NA & NA & NA \\
\hline Docosapentaenoic acid (C22:5n-3) & ND & ND & ND & ND & NA & NA & NA \\
\hline Docosahexaenoic acid, DHA (C22:6n-3) & ND & ND & ND & ND & NA & NA & NA \\
\hline Total SFA & 0.311 & 0.301 & 0.484 & 0.205 & 0.040 & 0.089 & 0.711 \\
\hline Total UFA & 0.562 & 0.577 & 0.932 & 0.400 & 0.080 & 0.109 & 0.856 \\
\hline Total MUFA & 0.365 & 0.371 & 0.625 & 0.276 & 0.056 & 0.123 & 0.936 \\
\hline Total PUFA & 0.198 & 0.206 & 0.307 & 0.134 & 0.025 & 0.089 & 0.686 \\
\hline n-6 PUFA & 0.190 & 0.197 & 0.295 & 0.128 & 0.023 & 0.089 & 0.686 \\
\hline n-3 PUFA & 0.004 & 0.003 & 0.008 & 0.003 & 0.001 & 0.180 & 0.678 \\
\hline UFA: SFA & $1.786^{\mathrm{b}}$ & $1.912^{\mathrm{a}}$ & $1.903^{\mathrm{a}}$ & $1.924^{\mathrm{a}}$ & 0.019 & 0.032 & 0.017 \\
\hline PUFA: SFA & 0.632 & 0.693 & 0.657 & 0.669 & 0.014 & 0.506 & 0.566 \\
\hline$(n-6):(n-3)$ PUFA & 23.68 & 16.75 & 30.76 & 18.45 & 3.679 & 0.556 & 0.961 \\
\hline
\end{tabular}

a, bMeans with various letters within the same row are substantially different $(p<0.05)$. CNTRL=Chicks given feed without additives, NOV25 $=$ Chicks given feed administrated with $0.25 \%$ novel additive, NOV50=Chicks given feed administrated with $0.50 \%$ novel additive, NOV100 $=$ Chicks given feed supplemented with $1.00 \%$ novel additive, SFA=Saturated fatty acid, UFA=Unsaturated fatty acid, MUFA=Monounsaturated fatty acid, PUFA=Polyunsaturated fatty acid, $A=A n a l y s i s$ of variance (ANOVA), L=Linear regression, SEM=Standard error of the means. ND=Not detected, NA=Not statistically analyzed

the treatment groups. A study by Pratama et al. [4] reported that fermented $A$. bilimbi L. fruit filtrate increased the villi length of jejunum of broilers. Similarly, wheat bran [21] and S. cerevisiae [22] have been confirmed to improve the intestinal morphology of broilers.
Our findings reveal no impact of the dietary additive on the yield of carcass and commercial proportions. This is consistent with Pratama et al. [4] who reported no significant effect of fermented A. bilimbi L. fruit filtrate on the broilers' carcass characteristics. Regarding wheat bran, Semjon et al. [23] reported no 
Table-7: Amino acid profiles of broiler meats.

\begin{tabular}{lccccccc}
\hline Items (g/kg) & \multicolumn{3}{c}{ Treatments } & SEM & p-value \\
\cline { 2 - 4 } & CNTRL & NOV25 & NOV50 & NOV100 & & A & L \\
\hline L-Histidine & 10.92 & 9.317 & 10.75 & 8.321 & 0.947 & 0.758 & 0.464 \\
L-Threonine & 10.75 & 11.92 & 13.06 & 11.58 & 0.428 & 0.303 & 0.356 \\
L-Proline & 7.349 & 13.25 & 9.747 & 7.051 & 1.231 & 0.262 & 0.698 \\
L-Tyrosine & $7.756^{\mathrm{b}}$ & $9.236^{\mathrm{ab}}$ & $12.54^{\mathrm{a}}$ & $7.846^{\mathrm{b}}$ & 0.687 & 0.036 & 0.571 \\
L-Leucine & 15.49 & 18.73 & 16.41 & 17.52 & 1.081 & 0.761 & 0.703 \\
L-Aspartate acid & 20.76 & 17.10 & 19.37 & 22.54 & 0.948 & 0.225 & 0.381 \\
L-Lysine & 20.34 & 19.53 & 16.54 & 20.99 & 1.085 & 0.504 & 0.915 \\
Glycine & 10.23 & 9.511 & 10.89 & 9.241 & 0.435 & 0.558 & 0.688 \\
L-Arginine & 14.43 & 13.42 & 17.53 & 15.28 & 0.852 & 0.385 & 0.392 \\
L-Alanine & 12.80 & 14.00 & 12.68 & 13.80 & 0.442 & 0.647 & 0.678 \\
L-Valine & 12.04 & 13.39 & 14.75 & 11.51 & 1.027 & 0.705 & 0.979 \\
L-Isoleucine & 10.66 & 12.22 & 11.01 & 10.75 & 0.497 & 0.686 & 0.836 \\
L-Phenylalanine & 9.473 & 13.76 & 13.62 & 10.17 & 1.070 & 0.359 & 0.842 \\
L-Glutamic acid & 34.41 & 28.64 & 26.05 & 38.34 & 2.205 & 0.191 & 0.650 \\
L-Serine & 9.106 & 12.64 & 10.33 & 9.222 & 0.644 & 0.183 & 0.741 \\
\hline
\end{tabular}

a,bMeans with various letters within the same row are substantially different $(p<0.05)$. CNTRL=Chicks given feed without additives, NOV25=Chicks given feed administrated with $0.25 \%$ novel additive, NOV50=Chicks given feed administrated with $0.50 \%$ novel additive, NOV100 $=$ Chicks given feed supplemented with $1.00 \%$ novel additive, $A=$ Analysis of variance (ANOVA), L=Linear regression, SEM=Standard error of the means

effect of fermented wheat bran on the carcass yield of broilers. Yalçın et al. [24] did not observe any impact of feeding $S$. cerevisiae on the yield. Regarding the $\mathrm{pH}$ value, high values are generally associated with a high WHC and high protein content in meats [25]. Our results reveal that the $\mathrm{pH}$ values of breast meat samples increased with increasing levels of feed additive and were correlated with increasing WHC. This study did not measure the protein content of breast meat. However, the literature suggests that dietary acidifiers increase protein digestibility, as well as protein biosynthesis, and reduce protein degradation in birds [26]. In addition, the dietary inclusion of probiotics and prebiotics increased protein availability and thus protein deposition (as a muscle protein) in the body of broilers [27]. For this reason, it is conceivable that $A$. bilimbi L. fruit filtrate (rich in organic acids), wheat bran (prebiotic source), and S. cerevisiae contributed to the increased protein biosynthesis, while reducing the protein breakdown, which was indicated by the higher $\mathrm{pH}$ values and WHC of meats.

The fatty acid profile is one of the most crucial factors determining the quality of broiler meats. In this study, the UFA-to-SFA ratio was notably higher in the breast meats of the treatment groups compared to those of the control. Del Puerto et al. [28] proposed the UFA-to-SFA ratio as a useful health indicator for meat, because a higher UFA-to-SFA ratio may protect consumers from hypercholesterolemia (a factor promoting atherosclerosis syndrome in humans). The feed additive proposed in this study may have this effect. A previous study reported that acidifiers reduced de novo synthesis of fatty acids in the liver, resulting in a lowered SFA content in broiler meat [10]. Similarly, Zhou et al. [29] reported that dietary supplementation of oligosaccharides lowered the SFA proportion in the breast muscle of broilers. Furthermore, Benamirouche et al. [30] reported decreased SFAs and increased UFAs in the breast meat of broilers fed with $S$. cerevisiae. Therefore, the proposed feed additive may contribute to lower de novo fatty acid synthesis and thus increase the UFA-to-SFA ratio. Our results show that the concentration of C20:3n-6 in the breast meat of broilers receiving $10 \mathrm{~g} / \mathrm{kg}$ additive was lower than that of broilers receiving 2.5 and $5.0 \mathrm{~g} / \mathrm{kg}$ additives. However, when comparing the treatments with the control, no such variation was observed.

Furthermore, the results reveal that L-glutamic acid was the most abundant of the amino acids in the breast meat (average $31.86 \mathrm{~g} / \mathrm{kg}$ ) followed by L-aspartate acid $(19.94 \mathrm{~g} / \mathrm{kg})$ and L-lysine $(19.35 \mathrm{~g} / \mathrm{kg})$. In addition, L-tyrosine was the least abundant amino acid $(9.34 \mathrm{~g} / \mathrm{kg})$. The concentration of L-tyrosine in the breast meat of broilers receiving the additive at $5.0 \mathrm{~g} / \mathrm{kg}$ was higher than that observed in control. A previous study reported that stress in chickens may be attributed to lowered tyrosine levels due to the increased dependence on the liver for synthesizing glucose, which is in part accomplished by the increased catabolism of glucogenic amino acids (including tyrosine) in the liver of chickens [31]. Therefore, we speculate that dietary administration of the proposed additive at $5 \mathrm{~g} / \mathrm{kg}$ may alleviate stress in birds and thereby prevent tyrosine catabolism in the liver. However, this is not entirely clear because the tyrosine level in the breast meat of broilers receiving $10 \mathrm{~g} / \mathrm{kg}$ additive was similar to that of the control. Finally, the concentrations of other glucogenic amino acids (i.e., threonine and glycine) did not change with the dietary administration of the proposed additive.

\section{Conclusion}

Dietary supplementation of the mixture of $A$. bilimbi L. fruit filtrate, wheat bran, and $S$. cerevisiae improved the live BW and FCR of broilers. The feed 
additive also improved the physical and nutritional qualities of broiler breast meats, which is indicated by the increased UFA-to-SFA ratio in the sampled meats.

\section{Authors' Contributions}

SS: Designed the experiment, analyzed data, and drafted the manuscript. ARP and TY: Conducted in vivo experiment. TA: Designed the experiment and revised the manuscript. All authors read and approved the manuscript.

\section{Acknowledgments}

The study was financially supported by Universitas Diponegoro through World Class Research Universitas Diponegoro, Indonesia, (WCRU) No. 118-06/UN7.6.1/PP/2021.

\section{Competing Interests}

The authors declare that they have no competing interests.

\section{Publisher's Note}

Veterinary World remains neutral with regard to jurisdictional claims in published institutional affiliation.

\section{References}

1. Nugroho, B.A. (2020) Indonesia's broilers business facing oversupply difficulties. IOP Conf. Ser. Earth Environ. Sci., 478: 012010.

2. Sugiharto, S. (2016) Role of nutraceuticals in gut health and growth performance of poultry. J. Saudi Soc. Agric. Sci., 15(2): 99-111.

3. Mareta, I., Nathaniel, G., Yudiarti, T., Widiastuti, E., Wahyuni, H.I. and Sugiharto, S. (2020) Effect of Averrhoa bilimbi fruit filtrate and shrimp paste mixture on performance, gut microbes and blood profile of broilers. Indones. J. Anim. Vet. Sci., 25(4): 182-189.

4. Pratama, A., Mareta, I., Yudiarti, T., Wahyuni, H.I., Widiastuti, E. and Sugiharto, S. (2021) Administration of fermented Averrhoa bilimbi L. fruit filtrate on growth, hematological, intestinal, and carcass indices of broilers. Trop. Anim. Sci. J., 44(1): 79-89.

5. Rodríguez, L.G.R., Mohamed, F., Bleckwedel, J., Medina, R., De Vuyst, L., Hebert, E.M. and Mozzi, F. (2019) Diversity and functional properties of lactic acid bacteria isolated from wild fruits and flowers present in Northern Argentina. Front. Microbiol., 10: 1091.

6. Kırkpınar, F., Açıkgöz, Z., Mert, S. and Işık, Ö. (2018) Effects of dietary probiotic, prebiotic and enzyme mixture supplementation on performance, carcass, organ, ileal ph and viscosity of broilers. J. Anim. Prod., 59(2): 1-9.

7. Tayeri, V., Seidavi, A., Asadpour, L. and Phillips, C.J.C. (2018) A comparison of the effects of antibiotics, probiotics, synbiotics and prebiotics on the performance and carcass characteristics of broilers. Vet. Res. Commun., 42(3): 195-207.

8. Li, B., Leblois, J., Taminiau, B., Schroyen, M., Beckers, Y., Bindelle, J. and Everaert, N. (2018) The effect of inulin and wheat bran on intestinal health and microbiota in the early life of broiler chickens. Poult. Sci., 97(9): 3156-3165.

9. Neyrinck, A.M., Hiel, S., Bouzin, C., Campayo, V.G., Cani, P.D., Bindels, L.B. and Delzenne, N.M. (2018) Wheatderived arabinoxylan oligosaccharides with bifidogenic properties abolishes metabolic disorders induced by western diet in mice. Nutr. Diabetes, 8: 15.

10. Galli, G.M., Aniecevski, E., Petrolli, T.G., da Rosa, G.,
Boiago, M.M., Simões, C.A.D., Wagner, R., Copetti, P.M., Morsch, V.M., Araujo, D.N., Marcon, H., Pagnussatt, H., Santos, H.V., Mendes, R.E., Loregian, K.E. and Da Silva, A.S. (2021) Growth performance and meat quality of broilers fed with microencapsulated organic acids. Anim. Feed Sci. Technol., 271: 114706.

11. Hussein, E. and Selim, S. (2018) Efficacy of yeast and multi-strain probiotic alone or in combination on growth performance, carcass traits, blood biochemical constituents, and meat quality of broiler chickens. Livest. Sci., 216: 153-159.

12. Tavaniello, S., Maiorano, G., Stadnicka, K., Mucci, R., Bogucka, J. and Bednarczyk, M. (2018) Prebiotics offered to broiler chicken exert positive effect on meat quality traits irrespective of delivery route. Poult. Sci., 97(8): 2979-2987.

13. Utama, C.S., Zuprizal, Hanim, C. and Wihandoyo. (2019) Pengaruh lama pemanasan terhadap kualitas kimia wheat pollard yang berpotensi sebagai prebiotik. J. Apl. Teknol. Pangan, 8(3): 113-122.

14. Sugiharto, S., Yudiarti, T., Isroli, I., Widiastuti, E., Wahyuni, H.I. and Sartono, T.A. (2018) The effect of fungi-origin probiotic Chrysonilia crassa in comparison to selected commercially used feed additives on broiler chicken performance, intestinal microbiology, and blood indices. J. Adv. Vet. Anim. Res., 5(3): 332-342.

15. SNI (Indonesian National Standard). (2015) Standard for Broiler Feed (SNI 8173.2:2015 and SNI 8173.3:2015). National Standardization Agency of Indonesia, Jakarta, Indonesia.

16. Bolton, W. (1967) Poultry Nutrition. MAFF Bulletin No.174. HMSO, London.

17. Grau, R. and Hamm, R. (1953) Eine einfache methode zur bestimmung der wasserbindung im Muskel. Naturwissenschaften, 40(1): 29-30.

18. Holland, B., Welch, A.A., Unwin, I.D., Buss, D.H., Paul, A.A. and Southgate, D.A.T. (1998) The Composition of Foods. The Royal Society of Chemistry, London.

19. Waters Corporation. (2012) Acquity UPLC H-class and H-class Bio Amino Acid Analysis (Manchester-Waters Corporation).

20. Moghaddam, H.N. and Alizadeh-Ghamsari, A.H. (2013) Improved performance and small intestinal development of broiler chickens by dietary L-glutamine supplementation. J. Appl. Anim. Res., 41(1): 1-7.

21. Shang, Q., Wu, D., Liu, H., Mahfuz, S. and Piao, X. (2020) The impact of wheat bran on the morphology and physiology of the gastrointestinal tract in broiler chickens. Animals, 10(10): 1831.

22. Erya, S.N., Wahyuni, H.I., Yudiarti, T., Widiastuti, E. and Sugiharto, S. (2020) Intestinal morphology and growth performance of the Indonesian indigenous crossbred chickens supplemented with formic acid and Saccharomyces cerevisiae. J. Indones. Trop. Anim. Agric., 45(4): 348-355.

23. Semjon, B., Bartkovský, M., Marcinčáková, D., Klempová, T., Bujňák, L., Hudák, M., Jad’uttová, I., Čertík, M. and Marcinčák S. (2020) Effect of solid-state fermented wheat bran supplemented with agrimony extract on growth performance, fatty acid profile, and meat quality of broiler chickens. Animals, 10(6): 942.

24. Yalçın, S., Eser, H., Yalçın, S., Cengiz, S. and Eltan, Ö. (2013) Effects of dietary yeast autolysate (Saccharomyces cerevisiae) on performance, carcass and gut characteristics, blood profile, and antibody production to sheep red blood cells in broilers. J. Appl. Poult. Res., 22(1): 55-61.

25. Mir, N.A., Rafiq, A., Kumar, F., Singh, V. and Shukla, V. (2017) Determinants of broiler chicken meat quality and factors affecting them: A review. J. Food Sci. Technol., 54(10): 2997-3009.

26. Khan, S.H. and Iqbal, J. (2016) Recent advances in the role of organic acids in poultry nutrition. J. Appl. Anim. Res., 44(1): 359-369. 
27. Rehman, A., Arif, M., Sajjad, N., Al-Ghadi, M.Q., Alagawany, M., Abd El-Hack, M.E., Alhimaidi, A.R., Elnesr, S.S., Almutairi, B.O., Amran, R.A., Hussein, E.O.S. and Swelum, A.A. (2020) Dietary effect of probiotics and prebiotics on broiler performance, carcass, and immunity. Poult. Sci., 99(12): 6946-6953.

28. del Puerto, M., Cabrera, M.C. and Saadoun, A. (2017) A note on fatty acids profile of meat from broiler chickens supplemented with inorganic or organic selenium. Int. J. Food Sci., 2017: 7613069.

29. Zhou, T.X., Chen, Y.J., Yoo, J.S., Huang, Y., Lee, J.H., Jang, H.D., Shin, S.O., Kim, H.J., Cho, J.H. and Kim, I.H.
(2009) Effects of chitooligosaccharide supplementation on performance, blood characteristics, relative organ weight, and meat quality in broiler chickens. Poult. Sci., 88(3): 593-600.

30. Benamirouche, K., Baazize-Ammi, D., Hezil, N., Djezzar, R., Niar, A. and Guetarni, D. (2020) Effect of probiotics and Yucca schidigera extract supplementation on broiler meat quality. Acta Sci. Anim. Sci., 42: e48066.

31. Ma, B., Zhang, L., Li, J., Xing, T., Jiang, Y. and Gao, F. (2021) Heat stress alters muscle protein and amino acid metabolism and accelerates liver gluconeogenesis for energy supply in broilers. Poult. Sci., 100(1): 215-223.

$* * * * * * * *$ 